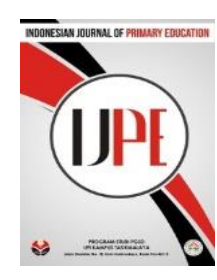

\title{
Upaya Meningkatkan Penguasaan Kosakata Bahasa Inggris melalui Model Scramble pada Siswa Kelas 4 SDN Jatimulya 04 Tambun Selatan
}

\author{
Rini Endah Sugiharti ${ }^{1}$, Yanti Riftina ${ }^{2}$ \\ PGSD- FKIP Universitas Islam 45 Bekasi \\ *Corresponding author: riniendahsugiharti@gmail.com, yanti.riftina@gmail.com \\ Diterima 20 Agustus 2018; Direview 18 September 2018; Diterima 15 Oktober 2018 \\ Diterbitkan online 28 Desember 2018
}

\begin{abstract}
.
The purpose of this research to increase English vocabularyfor the fourth grade students using Scramble model. This research is a Classroom Action Research (CAR) within two cycles with planning, action, observation, and reflection. Subjects of the research were 33 sudents of the fourth grade students of SDN Jatimulya 04 Tambun Selatan in the academic year of 2017/2018. Data analysis using quantitative analysis data. The result of this research show the application of Scramble model can increase students' English vocabulary. It was proven by the increase of classical achievement percentage of students' outcome in the pre-cycle 15,15\%, in the first cycle becomes 51,52\%, and in the second cycle becomes $87,88 \%$.
\end{abstract}

Keywords: vocabulary, Scramble Model

\section{ABSTRAK.}

Tujuan dari penelitian ini adalah meningkatkan penguasaan kosakata Bahasa Inggris siswa kelas IV SD menggunakan model Scramble. Penelitian ini merupakan Penelitian Tindakan Kelas (PTK) dalam dua siklus dengan tahapan perencanaan, pelaksanaan, pengamatan, dan refleksi. Subjek penelitian ini adalah siswa kelas IV SDN Jatimulya 04 Tambun Selatan tahun ajaran 2017/2018 sejumlah 33 siswa. Analisis data menggunakan analisis data kuantitatif. Hasil penelitian menunjukkan bahwa model Scramble dapat meningkatkan penguasaan kosakata siswa yang dibuktikan dengan perolehan persentase ketuntasan klasikal pra-siklus mencapai $15,15 \%$, pada siklus I meningkat menjadi 51,52\%, dan pada siklus II meningkat menjadi 87,88\%.

Kata kunci: kosakata, Scramble

\section{PENDAHULUAN}

Bahasa Inggris berperan sebagai alat komunikasi antar bangsa, baik secara lisan maupun tertulis. Dengan menguasai bahasa Inggris diharapkan generasi penerus bangsa tidak hanya mampu bertahan dalam era globalisasi, namun juga mampu bersaing dengan bangsa lainnya. Hal ini sesuai dengan penjelasan dari Peraturan Pemerintah Nomor 23 Tahun 2013, pasal 77I ayat (1), tentang muatan lokal pada struktur kurikulum SD/MI, bahwa bahasa asing terutama bahasa Inggris merupakan bahasa internasional yang sangat penting kegunaannya dalam pergaulan global. Dalam Suyanto (2015: 2) disebutkan bahwa mata pelajaran Bahasa Inggris, secara resmi diajarkan di Sekolah Dasar sejak tahun ajaran 1994 sebagai mata pelajaran muatan lokal yang diprogramkan di kelas 4, 5, dan 6 Sekolah Dasar.

Menurut Suyanto (2015: 43), dalam pembelajaran bahasa Inggris terdapat tiga komponen penting yang harus dipelajari dengan benar, yaitu kosakata (vocabulary), 
tata bahasa (grammar), dan pelafalan (pronounciation). Kosakata merupakan kumpulan kata yang dimiliki oleh suatu bahasa dan memberikan makna ketika digunakan. Tata bahasa merupakan pola dan aturan yang harus diikuti dalam mempelajari bahasa dengan benar. Pelafalan adalah cara mengucapkan kata-kata suatu bahasa. Rusmidah (2013: 1) berpendapat bahwa pengajaran kosakata memegang peranan yang sangat penting dalam pembelajaran bahasa Inggris, yang diarahkan untuk mengembangkan keterampilan-keterampilan berbahasa agar siswa mampu berkomunikasi dan berwacana dalam bahasa Inggris dengan baik. Untuk itu, diperlukan penguasaan kosakata dalam jumlah yang memadai.

Yulia (2013: 469) menyatakan, Penguasaan kosakata adalah kegiatan menguasai atau kemampuan memahami dan menggunakan kata-kata yang terdapat dalam suatu bahasa, baik bahasa lisan, maupun tulisan. Macam-macam penguasaan kosakata menurut Nurgiyantoro dalam Yulia (2013: 469) yaitu: (1) Penguasaan aktif-produktif, mencakup keterampilan berbicara dan menulis atau disebut juga encoding, yaitu proses usaha mengomunikasikan ide, pikiran, perasaan, melalui bentuk-bentuk kebahasaan yang berarti penguasaan secara ujaran lisan atau berbicara dan penulisan; (2) Penguasaan pasif-reseptif, mencakup keterampilan menyimak dan membaca atau disebut juga decoding, yang dapat diartikan pemahaman hanya terdapat dalam proses pemikiran.

Seseorang dikatakan menguasai kosakata apabila ia dapat menunjukkan kemampuan berbahasa dengan baik. Menurut Djiwandono dalam Linda (2016: 14), Indikator adanya penguasaan aktif-produktif terhadap kosakata ditunjukkan dalam bentuk kemampuan untuk menyebutkan kata sesuai dengan makna yang diminta, menyebutkan kata lain yang artinya sama atau mirip (sinonim) dengan suatu kata, menyebutkan kata lain yang artinya berlawanan (antonim), dan menuliskan kata sesuai dengan ejaan yang tepat. Selanjutnya, indikator adanya penguasaan pasif-reseptif terhadap kosakata ditunjukkan dalam bentuk kemampuan untuk menunjukkan benda, memilih kata sesuai dengan makna yang diberikan dari sejumlah kata yang disediakan, memilih kata yang memiliki arti sama atau mirip dengan suatu kata (sinonim), dan memilih kata yang memiliki arti yang berlawanan dengan suatu kata (antonim).

Suyanto (2015: 133-137) menyatakan, agar dapat berkomunikasi dengan baik dan jelas diperlukan kemampuan membedakan antara bunyi-bunyi bahasa. Salah ucapan dapat mengakibatkan salah pengertian atau salah paham. Salah dalam ucapan dan ejaan dapat membingungkan penyimak (pembaca) dan menyebabkan kestatisan dalam sistem komunikasi. Kemampuan mengeja dengan baik dan benar turut memperkaya kosakata dan menunjang keberhasilan telaah kosakata. 
Pemerolehan kosakata biasanya didahului dengan keterampilan membaca, kemudian siswa belajar lebih lanjut dari membaca (decoding) ke menulis (encoding) dengan menambah keterampilan mengenai pembedaan huruf (mengeja). Untuk itu, program mengeja yang paling efektif haruslah berjalan serentak dengan kegiatan telaah kosakata.

Suyanto (2015:142) berpendapat bahwa pada prinsipnya, pengajaran kosakata bertujuan membantu para siswa untuk memahami bahasa dan mengembangkan keterampilan mengeja mereka. Pengajaran ejaan tidak berdiri sendiri, melainkan ada hubungan yang erat antara ejaan dan konteks. Dengan menyajikan kata-kata yang hendak dieja dalam kalimat dapat membantu para siswa untuk menghubungkan satu kata dengan yang lainnya. Oleh karena itu perlu adanya solusi untuk mengatasi permasalahan tersebut yaitu dengan menerapkan model Scramble.

Menurut Shoimin (2014: 166-167), model Scramble merupakan metode yang berbentuk permainan acak kata, menyusun kata-kata dan huruf-huruf yang telah dikacaukan letaknya sehingga membentuk suatu kata tertentu yang bermakna, dengan penekanan latihan soal yang dikerjakan secara berkelompok.

Berdasarkan hasil pengamatan di SDN Jatimulya 04 Tambun Selatan menunjukkan bahwa penguasaan kosakata siswa masih rendah sehingga berdampak pada proses dan hasil belajar Bahasa Inggris siswa. Pada kenyataannya, penguasaan kosakata siswa secara lisan sudah cukup baik dan sudah sesuai dengan cara melafalkan kata, seperti yang diajarkan oleh guru. Sedangkan penguasaan kosakata siswa secara tulisan masih rendah, masih banyak siswa yang belum mampu menguasai kosakata bahasa Inggris dalam hal penulisan kata, baik penulisan perbendaharaan kata, sinonim dan antonim, maupun penulisan kata sesuai ejaan yang tepat. Seperti kita ketahui bahwa dalam bahasa Inggris, cara penulisan suatu kata dengan cara pengucapannya bisa berbeda, tidak seperti dalam bahasa Indonesia. Berbagai masalah diatas mengakibatkan nilai siswa rendah. Dapat dilihat dari persentase pencapaian nilai KKM siswa SDN Jatimulya 04 Tambun Selatan pada mata pelajaran Bahasa Inggris, dimana pada tahun ajaran 2014/2015 hanya sebanyak 64\% dari 34 siswa mencapai nilai KKM sebesar 65, 2015/2016 hanya sebanyak $66 \%$ dari 30 siswa mencapai nilai KKM sebesar 68, dan pada tahun ajaran 2016/2017 hanya sebanyak 67\% dari 31 siswa mencapai nilai KKM sebesar 70.

Berdasarkan latar belakang di atas, maka rumusan masalah dalam penelitian ini adalah: (1) bagaimana langkah-langkah penerapan Scramble dalam meningkatkan penguasaan kosakata Bahasa Inggris siswa kelas IV SDN Jatimulya 04 Tambun Selatan?, (2) apakah penerapan Scramble dapat meningkatkan penguasaan kosakata Bahasa Inggris siswa kelas IV SDN Jatimulya 04 Tambun Selatan?, 
(3) apa kendala dan solusi penerapan Scramble dalam meningkatkan penguasaan kosakata Bahasa Inggris siswa kelas IV SDN Jatimulya 04 Tambun Selatan.

Penerapan Scramble dalam meningkatkan penguasaan kosakata siswa sesuai dengan karakteristik siswa kelas IV SD. Menurut Suyanto (2015: 17), sebagai pemula, siswa kelas 4 sekolah dasar pada umumnya memiliki karakter sebagai berikut: (1) cenderung imajinatif dan aktif, (2) perasaan mudah bosan, (3) kehidupan anak-anak penuh warna dan keceriaan, (4) menyukai cerita sebagaimana mereka menyukai permainan, (5) nilai sosial mulai berubah, menyukai bekerjasama dalam kelompok, (6) mulai memiliki kesadaran dan kesiapan berbahasa, (7) menyukai percakapan untuk berinteraksi dan berbicara tentang apa yang dimiliki, (8) pembelajar yang merupakan pemikir yang aktif.

\section{METODE PENELITIAN}

Penelitian ini merupakan penelitian tindakan kelas (PTK) dengan model refleksi awal yang dimulai dengan refleksi awal atau dinamakan prapenelitian, sebagai langkah awal dalam perencanaan tindakan suatu PTK. Pada tahap refleksi awal sudah dilakukan diagnosis masalah penelitian. Penelitian dilaksanakan selama dua siklus yang masingmasing siklus terdiri dari perencanaan, pelaksanaan, pengamatan dan penilaian, diakhiri dengan refleksi. Penelitian ini dilaksanakan di SDN Jatimulya 04 Tambun
Selatan, dengan subjek penelitian siswa kelas IV semester 1 tahun ajaran 2017/2018 yang berjumlah 33 siswa. Sumber data berupa siswa, guru, dan dokumen. Teknik pengumpulan data yang digunakan adalah tes dan observasi. Alat pengumpulan data yang digunakan adalah instrumen tes tertulis dan daftar ceklis observasi. Analisis data yang digunakan adalah analisis data kuantitatif. Data dari implementasi hasil belajar peserta didik disesuaikan dengan target Kriteria Ketuntasan Minimal (KKM) yang harus diperoleh peserta didik, dikumpulkan selama beberapa siklus, diolah menjadi data kuantitatif, kemudian dianalisis secara deskriptif.

\section{HASIL PENELITIAN DAN} PEMBAHASAN

Penelitian tindakan kelas ini dilaksanakan dalam dua siklus dengan dua kali pertemuan pada setiap siklusnya. Setiap pertemuan dilaksanakan dengan alokasi waktu 2x35 menit. Masing-masing siklus dilaksanakan melalui empat tahap, yaitu perencanaan tindakan, pelaksanaan tindakan, pengamatan/penilaian tindakan, dan refleksi. Masing-masing siklus dilaksanakan dengan dua kali pertemuan, dimana pada pertemuan pertama merupakan penerapan model Scramble dan pada pertemuan kedua merupakan evaluasi hasil pembelajaran siswa setelah diterapkannya model Scramble.

Sebelum melakukan tindakan siklus I, peneliti terlebih dahulu melaksanakan 
kegiatan refleksi awal (pra penelitian). Berdasarkan observasi pada kondisi awal nilai mata pelajaran Bahasa Inggris siswa masih tergolong sangat rendah. Hanya beberapa siswa yang mampu mencapai nilai KKM. Hal ini disebabkan, bagi siswa kelas IV pelajaran Bahasa Inggris merupakan pelajaran yang masih baru karena mulai diajarkan di kelas IV. Berdasarkan hasil tes awal atau pre test yang diberikan kepada siswa, dapat disimpulkan beberapa hal sebagai berikut. Pertama, penguasaan kosakata siswa masih rendah. Kedua, masih banyak siswa yang belum mampu menguasai kosakata bahasa Inggris dalam hal penulisan kata, yaitu menyebutkan perbendaharaan kata secara tertulis sesuai dengan makna yang diminta oleh guru, menyebutkan sinonim dan antonim secara tertulis, maupun menuliskan kata sesuai dengan ejaan yang tepat. Seperti kita ketahui bahwa dalam bahasa Inggris, cara penulisan suatu kata dan cara pengucapannya bisa berbeda, tidak seperti dalam bahasa Indonesia. Ketiga, pencapaian rata-rata kelas dari hasil tes penguasaan kosakata siswa pada pra penelitian adalah sebesar 48,18 berada pada kualifikasi cukup. Keempat, perolehan ketuntasan klasikal sebesar $15,15 \%$ yaitu 5 siswa yang tuntas atau mencukupi nilai Kriteria Ketuntasan Minimal (KKM) sebesar 80, sedangkan 28 siswa atau $84,85 \%$ lainnya dengan kriteria tidak tuntas. Dengan demikian dapat disimpulkan bahwa penguasaan kosakata siswa kelas IV SDN Jatimulya 04 Tambun Selatan masih rendah.

Berdasarkan data pra penelitian ini maka berikutnya dilaksanakan penelitian siklus I dengan menerapkan model Scramble. Sesuai dengan pernyataan Shoimin (2014: 167), langkah-langkahnya sebagai berikut: (a) Persiapan. Guru menyiapkan bahan dan media yang akan digunakan dalam pembelajaran, kemudian membagi siswa menjadi beberapa kelompok. (b) Kegiatan Inti. Masing-masing kelompok berdiskusi mengerjakan soal, kemudian guru menganalisis hasil belajar siswa melalui diskusi kelas. (c) Tindak Lanjut. Guru mengupayakan tindak lanjut pembelajaran selanjutnya berdasarkan hasil belajar siswa. Hasil evaluasi setelah diterapkannya model Scramble adalah sebagai berikut; Pada siklus I jumlah nilai keseluruhan siswa sebesar 2508 , nilai rata-rata kelas sebesar 76,00, siswa yang mencapai nilai KKM (=80) sebanyak 17 orang dengan ketuntasan klasikal 51,52\%, nilai tertinggi siswa sebesar 100 sebanyak 2 siswa, nilai terendah siswa sebesar 40 sebanyak 2 siswa; Pada siklus II jumlah nilai keseluruhan siswa sebesar 2984, nilai rata-rata kelas sebesar 90,42, siswa yang mencapai nilai KKM (=80) sebanyak 29 orang dengan ketuntasan klasikal $87,88 \%$, nilai tertinggi siswa sebesar 100 sebanyak 3 siswa, nilai terendah siswa sebesar 68 sebanyak 2 siswa. Hasil penelitian pada siklus I dan siklus II memperlihatkan bahwa penguasaan kosakata 
Bahasa Inggris siswa kelas IV meningkat pada setiap siklusnya.

Peningkatan ini terjadi karena peneliti menerapkan model Scramble pada setiap siklus dengan langkah-langkah sebagai berikut: (1) Mempersiapkan perencanaan pembelajaran, menyiapkan bahan ajar berupa LKS yang berisi materi yang akan disampaikan yaitu "Sign in the Public Places", menyiapkan media pembelajaran berupa lembar kegiatan siswa yang dibuat dari karton asturo berwarna yang berisi gambar, soal latihan dan petunjuk jawaban berupa kata yang telah diacak hurufnya, juga potongan huruf dari origami berwarna sebagai jawaban dari soal yang ditempelkan sesuai dengan ejaan yang benar, kemudian membagi siswa menjadi beberapa kelompok. Media pembelajaran tersebut dibuat beragam warna untuk menyesuaikan karakteristik siswa kelas 4 SD. Sesuai pendapat Suyanto (2015: 17), Kegiatan dan tugas yang disertai gambar dan berwarna-warni akan membuat anak-anak lebih gembira. (2) Memberi kesempatan kepada siswa untuk mengerjakan soal yang telah diberikan dengan bekerjasama secara kelompok, kemudian menganalisis hasilnya bersama-sama dengan siswa melalui diskusi kelas. Pelaksanaan kegiatan siswa dilaksanakan secara berkelompok untuk menyesuaikan karakteristik siswa kelas 4 SD. Sesuai pendapat Suyanto (2015: 17), Dalam bekerjasama, anak-anak saling membantu dan mengoreksi, memberikan rasa aman pada siswa, meningkatkan rasa percaya diri dalam mempelajari bahasa baru, membantu anak menggunakan bahasa, dan membuat mereka saling belajar. Hubungan ini bisa terjalin melalui permainan, lagu, dan kegiatan belajar yang dilakukan secara berpasangan atau berkelompok. Sekali anak merasa aman dan senang dalam kelas bahasa Inggris, mereka bisa diberi semangat agar lebih berani dan lebih aktif. (3) Mengupayakan tindak lanjut pembelajaran selanjutnya berdasarkan hasil diskusi siswa, yaitu dengan memberikan tes di akhir siklus untuk menilai besarnya peningkatan penguasaan kosakata Bahasa Inggris siswa. Tes yang digunakan dalam penelitian ini yaitu tes objektif dan tes subjektif sebanyak dua puluh soal, yang terdiri dari empat soal menjodohkan, sebelas soal pilihan ganda, dan lima soal isian singkat. Menurut Asih (2016: 299), Pada umumnya pengukuran kemampuan pasifreseptif menggunakan tes objektif, sedangkan pengukuran kemampuan aktif-produktif menggunakan tes subjektif. Tes subjektif berupa uraian, yang bertujuan untuk mengukur kemampuan peserta didik menguraikan segala hal yang terdapat dalam pikirannya tentang suatu masalah yang diajukan guru, yang terdiri dari dua jenis yaitu uraian bebas dan uraian terbatas atau disebut juga isian singkat. Adapun tes objektif adalah tes yang penskorannya dapat dilakukan dengan tingkat objektivitas yang tinggi, yang terdiri dari empat jenis yaitu tes benar-salah, 
tes pilihan ganda, tes menjodohkan, dan tes melengkapi.

Berdasarkan pengamatan peneliti, setiap kali siswa diberi tugas untuk menyelesaikan lembar kerja yang berupa soal dan jawaban yang telah diacak susunannya, semua siswa tampak antusias menyelesaikan tugas tersebut dan menyenangi cara belajar yang diterapkan oleh guru. Bahkan di akhir pembelajaran, ketika guru menyampaikan kegiatan pembelajaran untuk pertemuan selanjutnya, siswa selalu meminta agar permainan tersebut dilakukan lagi pada pertemuan selanjutnya. Hal ini sesuai dengan pendapat Shoimin (2014:166) yang menyatakan bahwa Scramble dipakai untuk jenis permainan anakanak yang merupakan latihan pengembangan dan peningkatan wawasan pemikiran kosakata. Selain melatih ketepatan jawaban, juga melatih kecepatan, dalam hal ini waktu yang diberikan dalam menyelesaikan soal sangat terbatas.

Selain menyenangkan, pembelajaran dengan model Scramble juga berpengaruh terhadap ketepatan dan kecepatan siswa dalam menjawab soal evaluasi yang diberikan oleh guru. Pada siklus I, seluruh siswa berhasil menyelesaikan soal evaluasi dalam waktu tiga puluh menit. Pada siklus II, seluruh siswa berhasil menyelesaikan soal evaluasi dalam waktu dua puluh menit, lebih cepat sepuluh menit dibandingkan pelaksanaannya pada siklus I. Hal ini sesuai dengan pendapat Robert B. Taylor dalam
Huda (2014:303), bahwa Scramble merupakan salah satu metode pembelajaran yang dapat meningkatkan konsentrasi dan kecepatan berpikir siswa, yang menggabungkan kerja otak kanan dan otak kiri melalui permainan kata secara cepat dan tepat. Siswa tidak hanya diminta untuk menjawab soal, tetapi juga menerka dengan cepat jawaban soal yang sudah tersedia namun masih dalam kondisi acak. Ketepatan dan kecepatan berpikir dalam menjawab soal menjadi salah satu kunci permainan model pembelajaran Scramble. Kelebihan dari model Scramble yang diungkapkan dalam Huda (2014:306) sebagai berikut:

1) Melatih siswa untuk berpikir cepat dan tepat.

2) Mendorong siswa untuk belajar mengerjakan soal dengan jawaban acak.

3) Melatih kedisiplinan siswa.

\section{SIMPULAN}

Berdasarkan penerapan model Scramble yang digunakan untuk meningkatkan penguasaan kosakata Bahasa Inggris siswa kelas IV SDN Jatimulya 04 Tambun Selatan, dapat disimpulkan sebagai berikut: (1) Langkah-langkah penerapan model Scramble dalam upaya meningkatkan penguasaan kosakata Bahasa Inggris siswa kelas IV SDN Jatimulya 04 Tambun Selatan, yaitu: (a) Persiapan; Guru menyiapkan bahan dan media yang akan digunakan dalam pembelajaran, kemudian membagi siswa menjadi beberapa kelompok, (b) Kegiatan Inti; Masing-masing kelompok berdiskusi 
mengerjakan soal, kemudian guru menganalisis hasil belajar siswa melalui diskusi kelas, (c) Tindak Lanjut; Guru mengupayakan tindak lanjut pembelajaran selanjutnya berdasarkan hasil belajar siswa. (2) Penerapan model Scramble dapat meningkatkan penguasaan kosakata Bahasa Inggris siswa kelas IV SDN Jatimulya 04 Tambun Selatan yang dibuktikan dengan peningkatan pada setiap siklusnya, pada siklus I memperoleh nilai rata-rata 76,00 dengan perolehan persentase ketuntasan belajar klasikal sebesar 51,52 \%, dan pada siklus II memperoleh nilai rata-rata 90,42 dengan perolehan persentase ketuntasan belajar klasikal sebesar $87,88 \%$. Peningkatan penguasaan kosakata Bahasa Inggris secara signifikan tersebut membuktikan bahwa penelitian ini berhasil, (3) Terdapat kendala yang dihadapi dalam penerapan Scramble pada upaya peningkatan penguasaan kosakata Bahasa Inggris siswa kelas IV SDN Jatimulya 04 Tambun Selatan, yaitu: (a) siswa terlihat kurang bersemangat pada awal kegiatan pembelajaran, (b) siswa masih kurang aktif bertanya, menjawab pertanyaan guru, dan menyampaikan tanggapan saat pembelajaran, (c) siswa masih ribut dan belum tertib ketika pembagian kelompok, (d) ada beberapa siswa yang bergantian ijin ke kamar mandi pada saat guru menjelaskan materi, hal ini dinilai mengganggu pelaksanaan pembelajaran, (e) masih banyak siswa yang belum dapat menyebutkan kata sesuai dengan makna yang diminta oleh guru, memilih kata yang memiliki arti sinonim, memilih kata yang memiliki arti antonim, menyebutkan kata yang memiliki arti antonim, dan menuliskan kata sesuai ejaan yang tepat. Solusi untuk mengatasai berbagai kendala tersebut, yaitu: (a) siswa diberi variasi ice breaking sehingga membuat siswa lebih bersemangat, (b) siswa diberi pendekatan agar lebih berani dan percaya diri dalam memberikan pertanyaan atau memberikan jawaban, (c) siswa diberi arahan untuk mengatur pembagian kelompok, dan tidak ribut ketika mengerjakan tugas kelompok, (d) menerapkan peraturan, yaitu lima menit sebelum guru menjelaskan materi, siswa yang ingin ke kamar kecil dipersilahkan terlebih dahulu, sehingga ketika guru memulai menjelaskan materi, tidak ada lagi siswa yang ijin keluar kelas, (e) mengarahkan siswa dengan memberi contoh nyata yang mudah dijumpai dalam kegiatan siswa seharihari, sehingga dapat meningkatkan penguasaan kosakata Bahasa Inggris siswa.

Berdasarkan hasil penelitian yang telah dilaksanakan, ada beberapa saran, yaitu: (1) bagi sekolah diharapkan dapat memfasilitasi pelatihan model dan metode pembelajaran untuk guru-guru, dan mengijinkan guru menerapkan model Scramble sebagai salah satu model yang digunakan dalam pembelajaran, (2) bagi guru diharapkan dapat menggunakan model dan metode pembelajaran yang bervariasi, salah satunya model pembelajaran Scramble, (3) bagi siswa 
diharapkan dapat sering berlatih menguasai berbagai kosakata dengan menerapkan model Scramble ini, karena dengan terbiasa berlatih diharapkan dapat meningkatkan kemampuan siswa dalam menguasai kosakata dan menambah kosakata yang belum dikuasainya.

\section{DAFTAR PUSTAKA}

Abas, S. S. (2015). Penerapan Model Permainan Scramble Untuk Meningkatkan Penguasaan Kosakata Siswa Kelas IV SDN 38 Hulonthalangi Kota Gorontalo. Gorontalo: Universitas Negeri Gorontalo. [diakses pada tanggal 13 Agustus 2017]

Asih. (2015). Strategi Pembelajaran Bahasa Indonesia. Bandung: Pustaka Setia.

Astuti, L. D. (2016). Hubungan Penguasaan Kosakata Dengan Kemampuan Menulis Karangan Narasi Pada Siswa Kelas IV SDN Gugus Sultan Agung Kecamatan Pucakwangi Kabupaten Pati. Semarang: Universitas Negeri Semarang. http://download.portal garudaorg/article.php?article $=108470$ \&val=2671][diakses tanggal 21 Agustus 2017]

Huda, M. (2014). Model-model Pengajaran dan Pembelajaran: Isu-isu Metodis dan Paradigmatis. Yogyakarta: Pustaka Pelajar.

Kunandar. (2013). Langkah Mudah Penelitian Tindakan Kelas Sebagai Pengembangan Profesi Guru. Jakarta: PT Raja Grafindo Persada.

Peraturan Pemerintah Republik Indonesia Nomor 32 Tahun 2013 Tentang Perubahan Atas Peraturan Pemerintah Nomor 19 Tahun 2005 Tentang Standar Nasional Pendidikan.
Rusmidah, Suhartono, K. (2013). Penggunaan Model Word Square Dalam Peningkatan Penguasaan Kosakata Bahasa Inggris Siswa Kelas IV SDN Mangunranan. Surakarta: Universitas Sebelas Maret http://download.portal garudaorg/article.php?article $=108$ 470\&val=4073][diakses tanggal 21 Agustus 2017]

Shoimin, A. (2014). 68 Model Pembelajaran Inovatif dalam Kurikulum 2013. Yogyakarta: Ar-Ruzz Media.

Suyanto, Kasihani K. E. (2015). English For Young Learners: Melejitkan Potensi Anak Melalui English Class yang Fun, Asyik, dan Menarik. Jakarta: Bumi Aksara.

Tampubolon, S.(2013). Penelitian Tindakan Kelas. Jakarta: Erlangga.

Tarigan, H. G. (2015). Pengajaran Kosakata. Bandung: Angkasa.

Yesi, Ermawati, E. (2012). Hubungan Penguasaan Kosakata Dengan KeterampilanMenulis Argumentasi Siswa Kelas $X$ SMA Negeri 6 Padang. Padang: Universitas Negeri Padang. Jurnal Pendidikan Bahasa dan Sastra Indonesia, Volume 1 Nomor 1, September 2012, Seri E 339425[diakses tanggal 22 Agustus 2017]

Yulia, Emidar, Ena. (2013). Peningkatan Penguasaan Kosakata Melalui Teknik Permainan Teka-teki Silang di Kelas Vila SMPN 2 Sungai Penuh. Padang:Universitas Negeri Padang. [http://download.portalgaruda.org /article.php?Article $=101577 \& \mathrm{val}=1$ 517][diakses tanggal 21 Agustus 2017] 